\title{
Ontogeny of the trilobite Estaingia sinensis (Chang) from the lower Cambrian of South China
}

\author{
TAO DAI \& XINGLIANG ZHANG
}

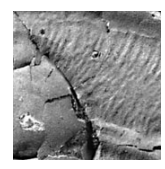

\begin{abstract}
New material collected from black shale of the lower Cambrian Shuijingtuo Formation in the Changyang County of Hubei Province, South China, allows a study on morphology and ontogeny of the trilobite Estaingia sinensis (Chang, 1953). Two protaspid stages can be defined on the basis of numerous well-preserved complete specimens, and subsequent ontogenetic stages are described largely based on the cranidia, which reveal prominent morphological changes such as the shortening of the frontal glabellar lobe, disappearance of the fixigenal spine and transformation of facial suture from proparian to opisthoparian. $\bullet$ Key words: Trilobita, Estaingia, ontogeny, Cambrian, South China.
\end{abstract}

DAI, T. \& ZHANG, X.L. 2012. Ontogeny of the trilobite Estaingia sinensis (Chang) from the lower Cambrian of South China. Bulletin of Geosciences 87(1), 151-158 (5 figures). Czech Geological Survey, Prague. ISSN 1214-1119. Manuscript received November 3, 2010; accepted in revised form October 4, 2011; published online February 2, 2012; issued February 29, 2012.

Tao Dai \& Xingliang Zhang (corresponding author), State Key Laboratory for Continental Dynamics, Early Life Institute and Department of Geology, Northwest University, Xian, 710069, P.R. China; xzhang69@nwu.edu.cn

The early Cambrian Shuijingtuo Formation (Chang 1953), exposed at Changyang, in western Hubei Province, South China (Fig. 1) contains a rich fauna of trilobites, dominated by two genera of eodiscoids: Tsunyidiscus Chang, 1966 and Sinodiscus Chang in Lu et al., 1974a and three genera of polymerids: Estaingia Pocock, 1964, Metaredlichia Lu, 1950 and Hunanocephalus (Duotingia) Chow in Lu et al., 1974b.

The well-preserved growth series of Estaingia sinensis (Chang, 1953) described and illustrated herein were all collected from carbonaceous shales of the lower part of this formation (Fig. 1C) which is overlain by yellowish-green, silty-shale and -mudstone of the Shipai Formation, but the base of the formation is not exposed in the section.

The trilobite Estaingia Pocock, 1964 has turned out to be widely distributed in the upper part of the traditional lower Cambrian, of which the type species is Estaingia bilobata Pocock, 1964. Subsequently, two additional species were described under this genus, i.e. E. sinensis Chang, 1953 and E. occipitospina Jell in Bengtson et al., 1990. The ontogeny of E. sinensis was first presented by Chang (1953), namely Lusatiops sinensis Chang, 1953 (Lusatiops is a senior synonymy of Estaingia, see Jell \& Adrain 2003), on the basis of 16 cranidia (including one protaspis, five meraspides and six holaspides), three fixigenae and an uncertain pygidium from the lower
Cambrian Shuijingtuo Formation in Changyang, western Hubei, China. Nevertheless, due to the poorly preserved specimens and lack of protaspis, the ontogenetic series was insufficiently described revealing limited information. In this paper the discovery of new material from the lower Cambrian Shuijingtuo Formation in Changyang County, Hubei Province, correlated to Qiongzhusian (Series 2, Stage 3 of the new Cambrian stratigraphical scheme), enables a detailed description of an ontogenetic sequence of Estaingia sinensis (Chang, 1953). In addition, an almost complete holaspid specimen is first illustrated herein.

\section{Material}

Exuviae of protaspid to holaspid specimens, preserved as external and internal moulds in the black shales, have been collected from the lower part of Shuijingtuo Formation in Changyang of Hubei Province, South China (Fig. 1). Due to the secondary diagenetic deformation, only well-preserved specimens including 32 protaspides, six meraspid cranidia, 39 holaspid cranidia and a nearly complete holaspis are described and discussed herein.

The measurements of sagittal length of the protaspid specimens are made from the anterior to posterior exoskeletal margins, excluding the length of posterior fixigenal 
spines. Sagittal length of the post-protaspid specimens are measured from anterior cranidial margin to occipital ring.

Described and figured material is housed in the collection of the Geological Department of Northwest University, Xi'an, China (NWUES 20201-20214).

\section{Systematic paleontology}

Terminology. - Morphological terms and abbreviations largely follow that of Whittington \& Kelly (1997), with modifications to protaspid terminology proposed by Edgecombe et al. (1988) and Lee \& Chatterton (1996, 1997). Anaprotaspis and metaprotaspis, proposed by Beacher (1895) and retained by Chatterton \& Speyer (see Kaesler 1997), are used as subdivisions of protaspid period by the presence of a shallow furrow behind the head. We follow the definition and accordingly, divide the protaspides herein into these two stages. In addition, some abbreviations and symbols used in the descriptions are listed below: exs. - exsagittal; L - length; LA - frontal glabellar lobe; LO - occipital ring; L1-L4 - glabellar lobes 1-4; sag. - sagittal; T - tergite; tr. - transverse; W - width; T1-T13 thoracic segments $1-13$.

Order Ptychopariida Swinnerton, 1915

Suborder Ptychopariina Richter, 1933

Superfamily Ellipsocephaloidea Matthew, 1887

Family Estaingiidae Öpik, 1975a

\section{Genus Estaingia Pocock, 1964}

Estaingia Pocock, 1964, p. 462; Öpik, 1975b, p. 10; Paterson, 2005, p. 89; Paterson \& Brock, 2007, p. 131.

Husaspis Chang in Lu et al. 1965, p. 85; Sun in Zhou et al., 1977, p. 123; Li in Yin \& Li, 1978, p. 427; Zhang \& Zhu, 1979, p. 516; Zhu in Zhang et al., 1980, p. 244; Li in Zhou et al., 1982, p. 227; Zhang in Qiu et al., 1983, p. 52; Sun, 1984, p. 347; Jell in Bengtson et al., 1990, p. 310; Palmer in Palmer \& Rowell, 1995, p. 16; Nedin, 1995, p. 36; Jago et al., 1997, p. 69.

Pseudichangia Chu \& Zhou in Lu et al., 1974, p. 93; Zhu in Zhang et al., 1980, p. 239; Sun, 1984, p. 346.

Strenax Öpik, 1975b, p. 13.

Zhuxiella Zhang \& Zhu in Zhang et al., 1980, p. 247; Sun, 1984, p. 348.

Type species. - Estaingia bilobata Pocock, 1964 from the early Cambrian Emu Bay Shale in Kangaroo Island, South Australia.

Discussion. - The synonymy of Hsuaspis, Pseudichangia, Strenax and Zhuxiella to Estaingia, has been discussed by
Jell in Bengtson et al. (1990), Jago et al. (1997), Paterson (2005) and Paterson \& Brock (2007).

\section{Estaingia sinensis Chang, 1953}

Figures 2-5

1953 Lusatiops sinensis Chang; p. 128, pl. 2, figs 1-16.

1957 Hsüaspis sinensis Chang et al.; p. 145, fig. 1.

1965 Hsüaspis sinensis Lu et al.; p. 87, pl. 13, figs 4-6.

1980 Hsüaspis sinensis Zhang et al.; p. 244, pl. 79, figs 6-9.

1999 ? gen. et spec. indet. 2, Zhang \& Pratt; p. 125, figs 3.5, 3.6, 7.1-7.8.

Discussion. - This species was originally described and referred to as Lusatiops sinensis by Chang (1953) and Hsüaspis sinensis by Chang et al. (1957). However, regarding the synonymy of Lusatiops, Hsüaspis and Estaingia (see Jell in Bengtson et al. 1990), it should now be referred to as Estaingia sinensis Chang, 1953.

\section{Ontogeny}

\section{Protaspid period}

Thirty-two protaspides of E. sinensis are investigated, 0.46 to $0.56 \mathrm{~mm}$ in length and 0.53 to $0.69 \mathrm{~mm}$ in width, of which two stages are recognized: anaprotaspides and metaprotaspides (Figs 2A-F, 4A, 5A, B).

Anaprotaspid stage. - Shield sub-elliptical in outline (excluding posterior spines), gently to moderately convex transversely and longitudinally, 0.46 to $0.54 \mathrm{~mm}$ long and 0.53 to $0.64 \mathrm{~mm}$ wide (Figs $2 \mathrm{~A}-\mathrm{C}, 5 \mathrm{~A}$ ). Anterior margin curved; anterior border narrow. Axis divided into 5 axial segments, anterior four as protoglabellar lobes (L1-L4), fifth as occipital ring (LO); slightly widening forward in L1-L3 and strongly expanded in L4, with anterior margin reaching anterior border, circa twice length (sag.) of L1-L3. A pair of fossulae located at junction of L4 and eye ridge. Eye ridge weakly to moderately developed, extending laterally and then curved posterolaterally, forming a continuation of palpebral lobe, with posterior tip situated opposite L2. Facial suture short, anterior sections convergent forward, posterior sections directed posterolaterally. Fixigena strongly convex, widest (tr.) between posterior tip of palpebral lobe and L2. Librigena extremely narrow (tr.), anterolaterally situated. Two pairs of marginal spines pointing backward; posterior pair extremely long.

Metaprotaspid stage. - Specimens in this phase vary from 0.49 to $0.56 \mathrm{~mm}$ in length and 0.60 to $0.69 \mathrm{~mm}$ in width, 


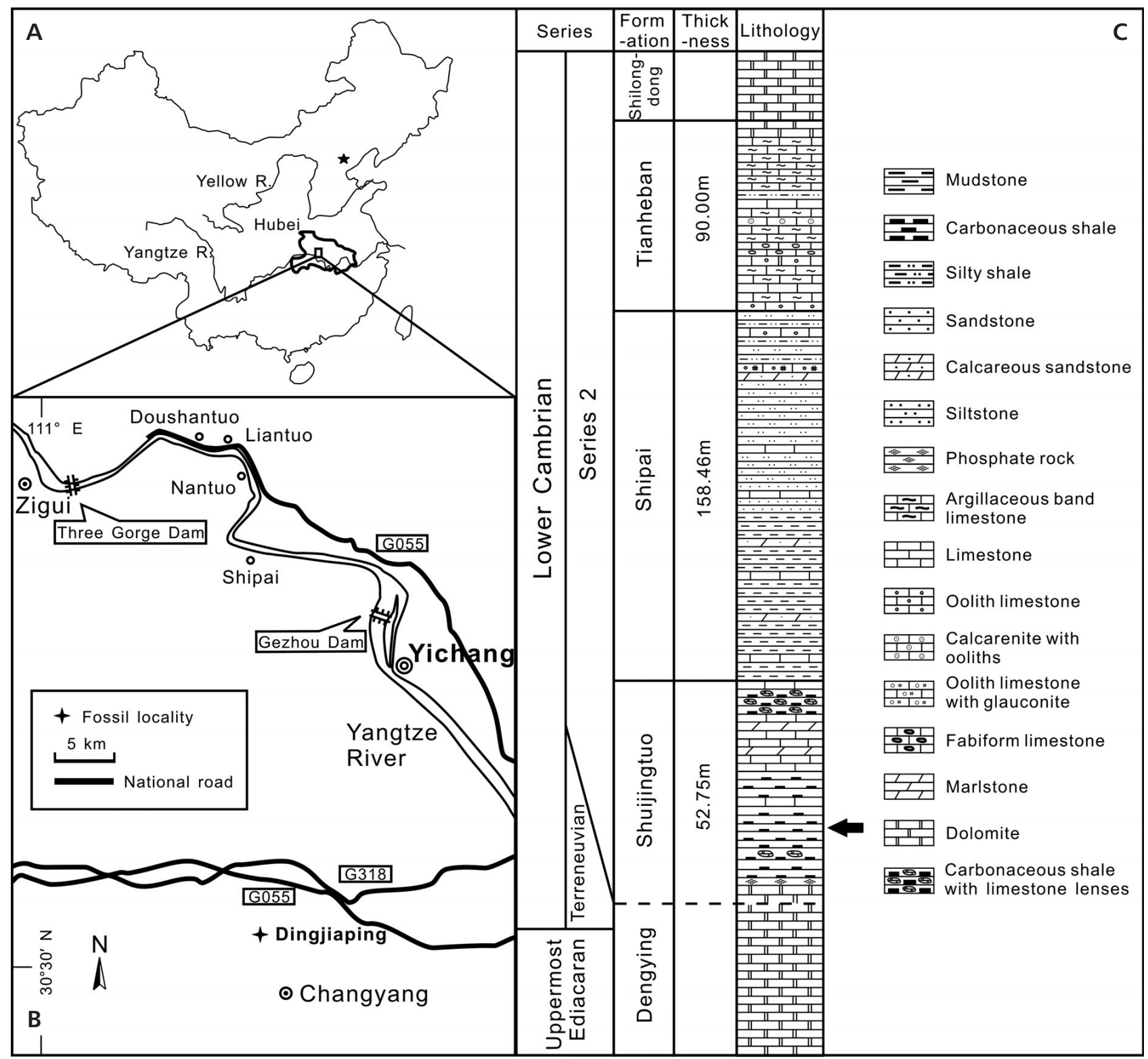

Figure 1. A - sketch map of the People's Republic of China, showing the position of collecting locality in the Hubei Province. • B - simplified geographical sketch map of the fossil locality Dingjiaping, $5.5 \mathrm{~km}$ from Changyang, Hubei Province, South China. $\bullet \mathrm{C}-$ stratigraphical sequences of lower Cambrian strata in the Three Gorge area, indicating the horizon where the fossils were collected (arrow).

characterized by the appearance of a shallow furrow and protopygidial area not clearly separated from the protocranidium (Figs 2D-F, 5B). Posterior cranidial margin extending laterally and curved backward to protocranidial spine. Protopygidium small, with posterior pair of spines shortened; one axial lobe defined by shallow axial furrow.

\section{Meraspid period}

Six meraspid cranidia, 0.53 to $1.04 \mathrm{~mm}$ long and 0.68 to $1.34 \mathrm{~mm}$ wide, are divided into two stages according to the direction of anterior sections of facial suture and disappearance of the fixigenal spine (Figs $2 \mathrm{G}-\mathrm{I}, 5 \mathrm{C}, \mathrm{D})$.

Stage 1. - Cranidium sub-rectangular in outline, 0.53 to $0.66 \mathrm{~mm}$ long and 0.68 to $0.76 \mathrm{~mm}$ wide (Figs $2 \mathrm{G}, \mathrm{H}, 5 \mathrm{C}$ ); anterior border moderately wide and flat; anterior border furrow shallow. Frontal glabellar lobe expanded forward, reaching anterior border furrow. Occipital ring wider than L1 (tr., sag.), posterior margin curved, occipital furrow straight. Facial suture proparian; anterior sections slightly convergent forward; posterior sections short, diverging posterolaterally. Eye ridge extending posterolaterally; 

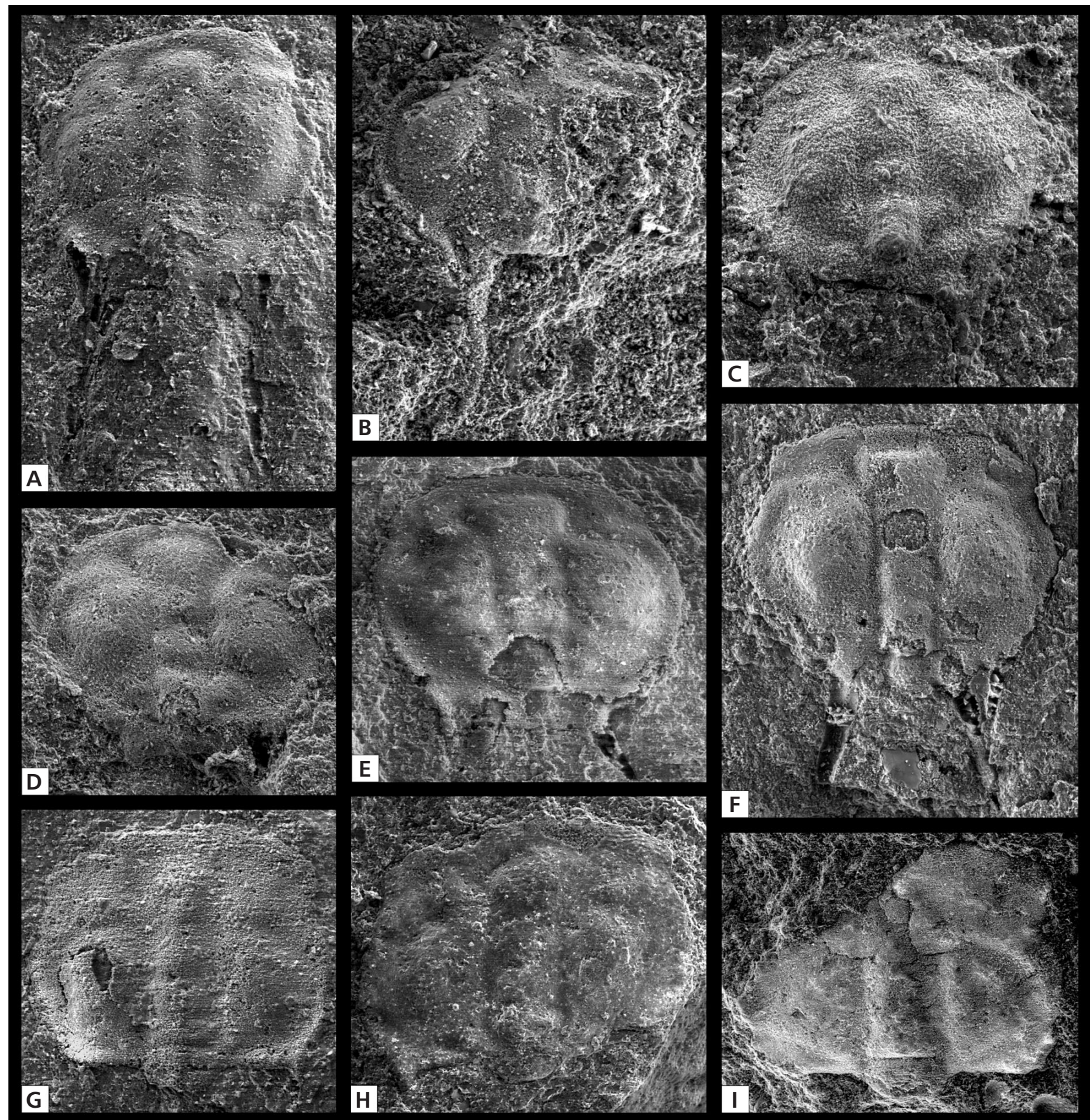

Figure 2. Protaspid and meraspid specimens of Estaingia sinensis (Chang, 1953) from Dingiaping, Changyang, Hubei, South China. $\bullet$ A-F - protaspid period. A-C - anaprotaspid stage, NWUES 20201-20203, × 75, × 70, × 74; D-F, metaprotaspid stage, NWUES 20204-20206, × 74, × 70, × 86. - G-I - meraspid period. G-H, stage 1, NWUES 20207-20208, × 60, × 75; I, stage 2, NWUES 20209, × 42.

palpebral lobe curved with posterior tip situated opposite L2. Posterior border furrow weakly impressed. Fixigenal spine tapering backward.

Stage 2. - Four specimens varying from 0.83 to $1.04 \mathrm{~mm}$ long and 1.05 to $1.34 \mathrm{~mm}$ wide (Figs 2I, 4D). Preglabellar field extremely narrow. Anterior sections of facial suture slightly divergent forward. Fixigenal spine indistinct or absent. Palpebral lobe with posterior tip situated opposite $\mathrm{S} 1$.

Compared with the protaspid phase, the meraspides possess several morphological changes which include: wider anterior cranidial border; preglabellar field present; frontal glabellar lobe less prominent; fossulae disappeared; occipital ring wider than L1 (tr.); eye ridge and palpebral lobe more prominent, with posterior tip 

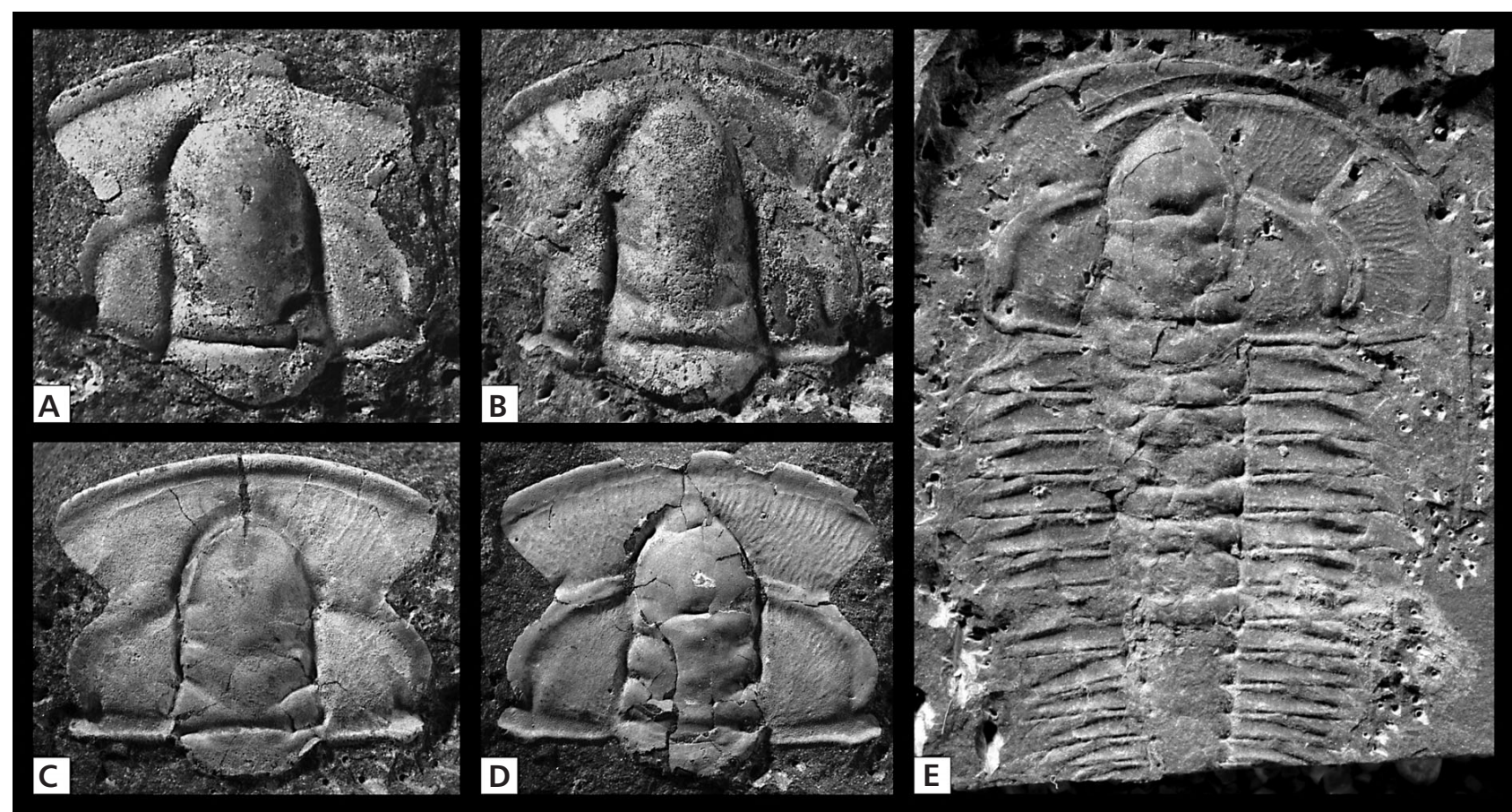

Figure 3. Holaspid specimens of Estaingia sinensis (Chang, 1953) from Dingjiaping, Changyang, Hubei, South China. • A, B - cranidia of early stage, NWUES 20210-20211, ×9, × 7. C-E - late stage, C, D - cranidia, E - nearly complete specimen with 13 thoracic segments, NWUES 20212-20214, $\times 5, \times 4, \times 9$.

opposite $\mathrm{S} 1$; fixigenal spine minute by degrees and probably disappeared in meraspid stage 2; fixigenal lobes less prominent.

\section{Holaspid period}

Thirty-nine cranidia and one nearly complete specimen are assigned to this period and divided into two stages, according to the size and morphological characteristics which comprise the sagittal elongation of preglabellar field and direction of eye ridge and palpebral lobe (Figs 3A-E, 4B, $5 \mathrm{E}, \mathrm{F})$.

Early holaspid stage. - This stage is represented by five cranidia ranging from 4.5 to $5.9 \mathrm{~mm}$ in length and 4.6 to $5.5 \mathrm{~mm}$ in width (Figs $3 \mathrm{~A}, \mathrm{~B}, 5 \mathrm{E}$ ). Cranidium sub-rectangular in outline. Anterior margin subacute medially; anterior border of moderate width (sag.) and convexity, equal in length (sag., exs.) abaxially; anterior border furrow shallow. Glabella wide and convex, rising above fixigenae; LA rounded with anterior margin in a short distance from anterior border; three pairs of glabellar furrows discontinuous, projecting posteromedially. Occipital ring convex (tr., sag.), posterior margin bowed backward; occipital spine indistinct, located posteromedially. Eye ridge and palpebral lobe of moderate convexity, extending from S3 and then curved posterolaterally, with posterior tip close to posterior border and opposite L1. Facial suture opisthoparian; anterior sections long, diverging anterolaterally between $\gamma$ and $\beta$, then convergent forward between $\beta$ and $\alpha$; posterior sections short, diverging posterolaterally then cutting posterior border. Fixigena narrow (tr.), fixigenal spine absent. Posterior border narrow and convex (exs.), slightly expanding abaxially to intergenal angle, then tapering to distal end of border.

Late holaspid stage. - This stage is represented by 35 specimens, 6.8-11.5 mm in cranidial length (Figs 3C-E, 5F). Cranidium subquadrate in outline. Anterior margin curved medially; anterior border slightly wider (sag.) and downsloping inward to border furrow; preglabellar field wider (sag.); glabellar furrows deeper and more incised; anterior sections of facial suture more divergent; eye ridge and palpebral lobe extending more laterally and then curved backward; fixigenal field wider (tr.). Fine ridges are well preserved on the exosketelons of the fixigena and librigena, showing radiating pattern of genal caeca.

Thorax with at least 13 segments, probably bearing 13 to 15 segments in adults; thoracic segments narrower (exs., tr.) posteriorly from $\mathrm{T} 1$ to T13. Axial rings poorly preserved, with posterior margin curved backward, lacking axial spines. Pleural furrows wide (exs.) and shallow; pleural spines pointing posterolaterally. 

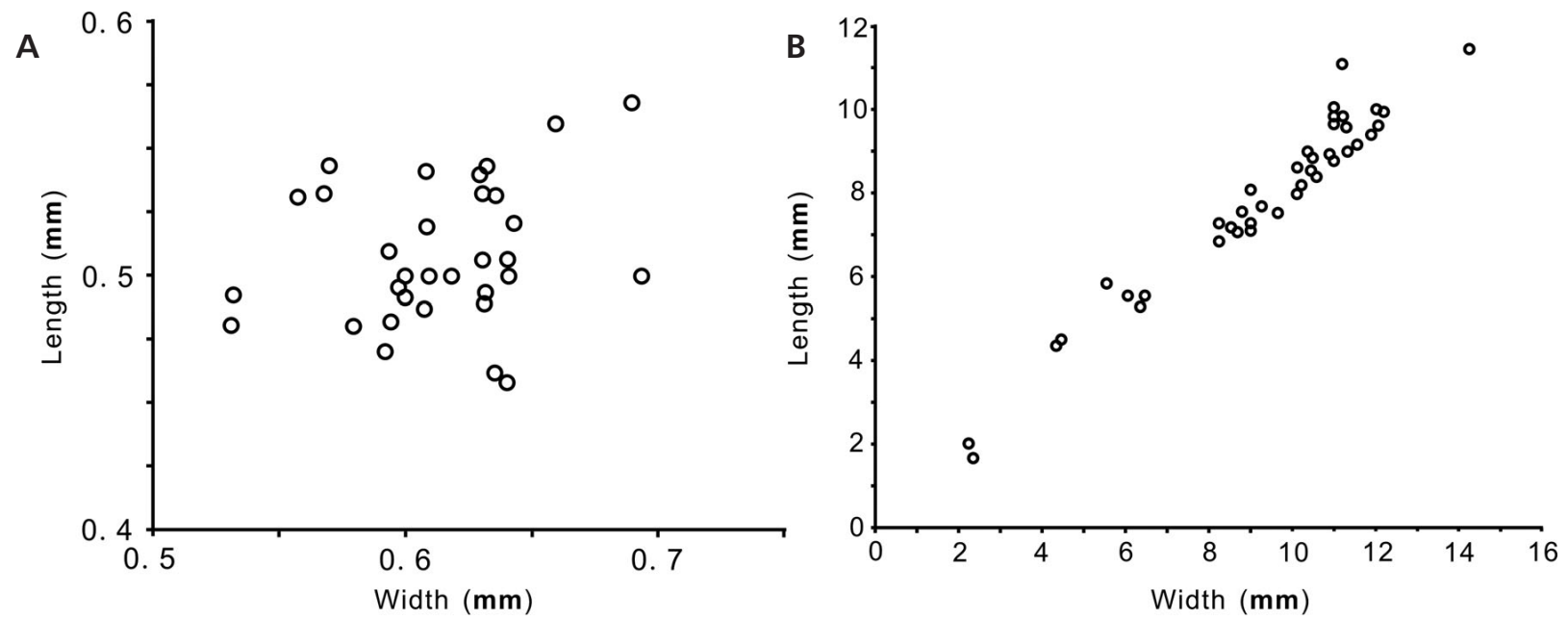

Figure 4. Scatter diagram of length vs. width of protaspides (A, $n=32$ ) and holaspides (B, $n=40)$ of Estaingia sinensis (Chang, 1953) from Yichang and Changyang, Hubei, South China.
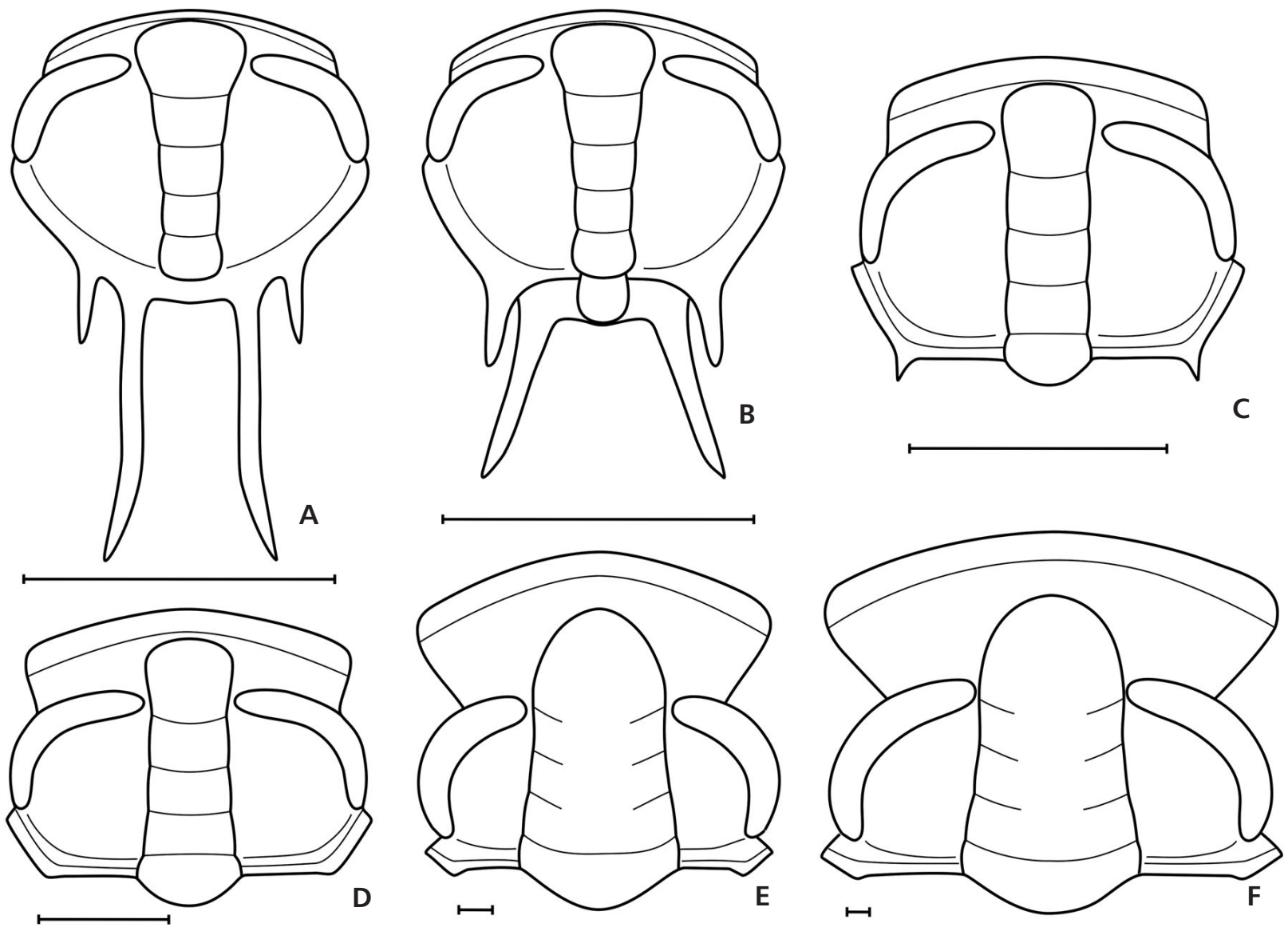

Figure 5. Reconstruction of dorsal views of ontogenetic series of Estaingia sinensis (Chang, 1953). - A, B - protaspid period, A - anaprotaspis, B - metaprotaspis. $\bullet$ C, D - meraspid period, C - stage 1, D - stage 2. E E, F - holaspid period, E - early stage, F - late stage. Scale bars $0.5 \mathrm{~mm}$.

\section{Summary of morphological variation during ontogeny}

The exoskeletal length of $E$. sinensis increases from $0.46 \mathrm{~mm}$ in the protaspis to $21.5 \mathrm{~mm}$ in the almost complete holas- pis. As to the overall ontogenetic trends from protaspis to holaspis, some of which are summed up as follows: anterior cranidial border becomes wider (sag.) and more convex; axial furrow becomes more deeper and incised; preglabellar field appeared in meraspides and becomes wider 
(sag.) in holaspides; glabella more protuberant in holaspid period, with three pairs of glabellar furrows from transverse in meraspides to discontinuous in holaspides; fixigenal spine minute by degrees and disappeared till meraspid stage 2; eye ridge and palpebral lobe with posterior tip closer to glabella and posterior border during ontogeny; facial sutures change from proparian in meraspides to opisthoparian in holaspides, with anterior sections from convergent to divergent in meraspid stage 2 ; decrease in the L/W ratio of cranidium.

\section{Discussion}

Chang (1953) briefly described an incomplete ontogenetic sequence of $E$. sinensis, of which the post-embryonic development of the cranidia comprised three periods. The protaspid period was represented by only one late protocranidium (figs 2.1, 2.34). The meraspid period was subdivided into three stages mainly based on the size, and the first and second stages (figs 2.2-6, 2.35) cannot be distinguished morphologically, which might correspond to meraspid stage 1 herein. In addition, the specimens assigned to holaspid period, revealing limited information, were subdivided into two stages (figs 2.7-12, 2.34). Much more complete ontogenetic sequences summarized in this paper, especially the discovery of the nearly complete holaspid specimen, significantly increase our knowledge on the ontogeny of this species.

Additionally, Zhang \& Pratt (1999) described the material of protaspid and meraspid period assigned to 'genus and species indeterminate 2' based on excellently preserved phosphatized specimens from the lower Cambrian Shuigoukou Formation from the Laozizhai section in Xichuan, Henan Province, China, which might be assigned to E. sinensis in this study. According to Zhang \& Pratt (1999), the protaspides were subdivided into two stages, i.e. 'stage 0' (figs 3.5, 7.1, 7.2) and 'stage 1' (figs 3.6, 7.3-6.5), which could correspond to anaprotaspides herein due to the absence of a shallow furrow distinguishing the pygidial portion from the protocranidium. The meraspides with fixigenal spine and slightly convergent anterior sections of facial suture described by Zhang \& Pratt (1999, figs $7.6,7.7$ ) could correspond to meraspid stage 1 in this paper; one meraspis (fig. 7.8) is comparable to the meraspid stage 2 herein due to the disappearance or shortening of the fixigenal spine and divergent anterior sections of facial suture.

\section{Acknowledgments}

We thank Liu Wei and Lei Ming for their help in collecting specimens in the field. Financial supports by the Natural Science
Foundation of China (NSFC, Grants: 40872004, 40925005 and 40830208) and the Major Basic Research Project of the Ministry of Science and Technology of China (Grant: 2006CB806400) are greatly acknowledged.

\section{References}

BEECHER, C.E. 1895. The larval stages of trilobites. The American Geologist 16, 166-197.

Bengtson, S., Morris, S.C., Cooper, B.J., Jell, P.A. \& RunNEGAR, B.N. 1990. Early Cambrian fossils from South Australia. Memoirs of the Association of Australasian Palaeontologists 9, 1-364.

Chang, W. 1953. Some Lower Cambrian trilobites from western Hupei. Acta Palaeontologica Sinica 1, 121-149.

Chang, W. 1966. On the classification of Redlichiacea, with description of new families and new genera. Acta Palaeontologica Sinica 14, 135-184. [in Chinese with English summary]

Chang, W., Lee, C., Chien, I., Chu, C., Chen, C. \& Chang, S. 1957. Brief note on the Cambrian and Ordovician stratigraphy of the Gorge District of the Yangtze. Chinese Science Bulletin 5, 145-146. [in Chinese]

Edgecombe, G.D., Speyer, S.E. \& Chatterton, B.D.E. 1988. Protaspid larvae and phylogenetics of encrinurid trilobites. Journal of Paleontology 62, 779-799.

Jago, J.B., Lin, T., Davidson, G., Stevens, B.P.J. \& Bentley, C. 1997. A late Early Cambrian trilobite faunule from the Gnalta Group, Mt Wright, NSW. Transactions of the Royal Society of South Australia 121, 67-74.

Jell, P.A. \& Adrain, J.M. 2003. Available generic names for trilobites. Memoirs of the Queensland Museum 48, 331-553.

LeE, D.C. \& Chatterton, B.D.E. 1996. Terminology of glabellar lobes in trilobite larvae based on homology. Journal of Paleontology 70, 439-442.

LeE, D.C. \& Chatterton, B.D.E. 1997. Ontogenies of trilobites from the Lower Ordovician Garden City Formation of Idaho and their implications for the phylogeny of the Cheirurina. Journal of Paleontology 71, 683-702.

Lu, Y. 1950. On the genus Redlichia with description of its new species. Geological Review 15, 157-169.

Lu, Y., Zhang, W., Qian, Y., Zhu, Z., Lin, H., Zhou, Z., Qian, Y., Zhang, S. \& Wu, H. 1974a. Cambrian trilobites, 82-107. In Nanjing Institute of Geology and Palaeontology, ACADEMICA Sinica (ed.) Handbook of stratigraphy and palaeontology in southwestern China. 454 pp. Science Press, Beijing. [in Chinese]

Lu, Y., Zhang, W., Zhu, Z., Qian, Y. \& Xiang, L. 1965. Chinese fossils of all group, Chinese trilobites. 766 pp. Science Press, Beijing. [2 volumes in Chinese]

Lu, Y., Zhu, Z., Qian, Y., Zhou, Z. \& Yuan, K. 1974b. Bio-environmental control hypothesis and its application to Cambrian biostratigraphy and palaeozoogeography. Memoir of the Nanjing Institute of Geology and Palaeontology, Academia Sinica 5, 27-110. [in Chinese] 
Matthew, G.F. 1887. Illustrations of the fauna of the St. John Group. 4. Part 1. Description of a new species of Paradoxides (Paradoxides regina). Part 2. The smaller trilobites with eyes (Ptychopariidae and Ellipsocephalidae). Transactions of the Royal Society of Canada 5(4), 115-166.

Nedin, C. 1995. The Emu Bay Shale, a lower Cambrian fossil lagerstätten, Kangaroo Island, South Australia. Memoirs of the Association of Australasian Palaeontologists 18, 31-40.

ÖPIK, A.A. 1975a. Templetonian and Ordian xystridurid trilobites of Australia. Bureau of Mineral Resources, Geology and Geophysics Bulletin 121, 1-84.

ÖPIK, A.A. 1975b. Cymbric Vale fauna of New South Wales and Early Cambrian biostratigraphy. Bureau of Mineral Resources, Geology and Geophysics Bulletin 159, 1-74.

Palmer, A.R. \& Rowell, A.J. 1995. Early Cambrian trilobites from the Shackleton Limestone of the Central Transantarctic Mountains. Paleontological Society Memoir 45, 1-28.

PAterson, J.R. 2005. Revision of discomesites and Estaingia (Trilobita) from the Lower Cambrian Cymbric Vale Formation, western New South Wales: Taxonomic, biostratigraphic and biogeographic implications. Proceedings of the Linnean Society of New South Wales 126, 81-93.

PAterson, J.R. \& BRock, G.A. 2007. Early Cambrian trilobites from Angorichina, Flinders Ranges, South Australia, with a new assemblage from the Pararaia bunyerooensis Zone. Journal of Paleontology 81, 116-142. DOI 10.1666/0022-3360(2007)81[116:ECTFAF]2.0.CO;2

Poсоск, K.J. 1964. Estaingia, a new trilobite genus from the Lower Cambrian of South Australia. Palaeontology 7, 458-471.

Qiu, H., Lu, Y., Zhu, Z., Bi, D., Lin, T., Zhou, Z., Zhang, Q., Qian, Y., Ju, T., Han, N. \& WeI, X. 1983. Trilobita, 28-254. In Nanjing Institute of Geology and Mineral Resources (ed.) Paleontological Atlas of East China, Part 1, Early Paleozoic. Geological Publishing House, Beijing. [in Chinese]

RichTER, R. 1933. Handwörterbuch der Naturwissenschaften (second edition), Vol. 2, Crustacea (Paläontologie), 840-864. Gustav Fischer, Jena.
Sun, Z. 1984. Trilobita, 328-422. In Regional Geological SuRveying Team of Hubei (ed.) Paleontological Atlas of Hubei Province. Hubei Science and Technology Press, Wuhan. [in Chinese]

Swinnerton, H.H. 1915. Suggestions for a revised classification of trilobites. Geological Magazine (New Series) 6(2), 487-496, 538-545. DOI 10.1017/S0016756800203634

Whittington, H.B. \& Kelly, S.R.A. 1997. Morphological terms applied to Trilobita, 313-329. In KAEsLER, R.L. (ed.) Treatise on Invertebrate Paleontology. Part O. Arthropoda 1, Trilobita (revised). Geological Society of America \& University of Kansas Press, Lawrence.

Yin, G. \& Li, S. 1978. Trilobita, 385-595. In Chengdu Institute of Geology and Mineral Resources (ed.) Palaeontological Atlas of Southwest China, Guizhou Province, Part 1. 843 pp. Geological Publishing House, Beijing. [in Chinese]

Zhang, W. \& Zhu, Z. 1979. Notes on some trilobites from the Lower Cambrian Houjiashan Formation in southern and southwestern parts of North China. Acta Palaeontogica Sinica 18, 513-525. [in Chinese with English summary]

Zhang, W., Lu, Y., Zhu, Z., Qian, Y., Lin, H., Zhou, Z., Zhang, S. \& YUAN, J. 1980. Cambrian trilobite faunas of southwestern China. Palaeontologica Sinica, New Series B 16, 497 pp. [in Chinese with English summary]

Zhang, X. \& Pratt, B.R. 1999. Early Cambrian trilobite larvae and ontogeny of Ichangia ichangensis, 1957 (Protolenidae) from Henan, China. Journal of Paleontology 73, 117-128.

Zhou, T., Liu, Y., Meng, X. \& Sun, Z. 1977. Trilobita, 107-266. In WANG, X. (ed.) Palaeontological Atlas of Central and South China, Guizhou 1. 420 pp. Geological Publishing House, Beijing. [in Chinese]

Zhou, Z., Li, J. \& Qu, X. 1982. Trilobita, 215-294. In XI’ An Institute of Geology and Mineral Resource (ed.) Paleontological Atlas of Northwest China, Shaanxi-Gansu-Ningxia 1, Precambrian and Early Paleozoic. Geological Publishing House, Beijing. [in Chinese] 